\title{
Remediation of Arsenic Toxicity in the Soil-Plant System by Using Zinc Fertilizers
}

\author{
Ishrat Jahan Sanchary', Shah Muhammad Imamul Huq ${ }^{2 *}$ \\ ${ }^{1}$ Department of Soil and Environmental Sciences, University of Barisal, Barisal, Bangladesh \\ ${ }^{2}$ Department of Soil, Water and Environment, University of Dhaka, Dhaka, Bangladesh \\ Email: ^ijsanchary@gmail.com
}

How to cite this paper: Sanchary, I.J. and Huq, S.M.I. (2017) Remediation of Arsenic Toxicity in the Soil-Plant System by Using Zinc Fertilizers. Journal of Agricultural Chemistry and Environment, 6, 30-37. https://doi.org/10.4236/jacen.2017.61002

Received: October 27, 2016

Accepted: December 3, 2016

Published: December 6, 2016

Copyright () 2017 by authors and Scientific Research Publishing Inc. This work is licensed under the Creative Commons Attribution International License (CC BY 4.0).

http://creativecommons.org/licenses/by/4.0/ (c) (i) Open Access

\begin{abstract}
Availability of soil arsenic (As) and plant As at various levels of zinc (Zn) and As applications were examined. A pot-culture experiment with a leafy vegetable, Kalmi (Ipomoea aquatica), on an Inceptisols, was conducted where As was applied with irrigation water at the rates of $0 \mathrm{mg} / \mathrm{L}$ (As control), $0.5 \mathrm{mg} / \mathrm{L}$, $1 \mathrm{mg} / \mathrm{L}$ and $2 \mathrm{mg} / \mathrm{L}$ and $\mathrm{Zn}$ was added to the soil as $\mathrm{ZnCl}_{2}$ solution at the rate of $0 \mathrm{mg} / \mathrm{L}$ (Zn control), $1 \mathrm{mg} / \mathrm{L}, 2 \mathrm{mg} / \mathrm{L}$ and $3 \mathrm{mg} / \mathrm{L}$ during pot preparation. The experiment was conducted in triplicates for 45 days till the plants were grown to maturity. At the end of the experiment the remedial effect of $\mathrm{Zn}$ on As toxicity was examined and as such, yield parameters, As and $\mathrm{Zn}$ accumulation in Kalmi plants, residual concentrations of $\mathrm{As}$ and $\mathrm{Zn}$ in soils and plants were measured. It appeared from the present study that there exists an antagonistic relationship between $\mathrm{Zn}$ and As i.e., $\mathrm{Zn}$ in soils was found to reduce As availability in soils as well as its accumulation in plants, particularly at an elevated application rate of $3 \mathrm{mg} / \mathrm{L} \mathrm{Zn}$. The findings could be used as a strategy to mitigate arsenic toxicity in As contaminated soils.
\end{abstract}

\section{Keywords}

Remediation, Arsenic, Soil-Plant System

\section{Introduction}

Arsenic is a proven potent killing agent. It has been termed as the biggest natural calamity in known human history of the world. Ground water contamination by As has been reported in 20 countries of the world encompassing all the continents [1] but the extent of ground water contamination in Bangladesh is by far the most severe as it covers almost $80 \%$ of the country with about $50 \%$ of the population at exposure risk of different degrees and the source is mainly geogenic [2]. 
About $40 \%$ of total arable land in Bangladesh is now under irrigation facilities and more than $60 \%$ of this irrigation is met from groundwater, most of which is contaminated with As to variable extent [2]. As arsenic contaminated groundwater is being used for irrigation purpose, there is a risk of soil accumulation as well as possible creeping of this toxic element to the food chain through plant uptake and animal consumption [3]. It may cause hazards both in soil environment and in crop quality. Normal level of As in soils is $4-8 \mathrm{mg} \mathrm{As} / \mathrm{kg}$, but in areas where As contaminated ground water is used for irrigation, the soil As level can reach up to $58 \mathrm{mg} \mathrm{As} / \mathrm{kg}$ [4].

On the other hand, $\mathrm{Zn}$ is an essential micronutrient element for plants [5]. It is reported to involve in some important plant metabolic processes like enzyme activation, especially carbonic anhydrase and enolase [6], protein production [7], growth hormone (especially auxin) formation and chlorophyll formation [8], pollination by pollen tube formation [9] [10] [11] and pigment formation for photosynthesis [12].

As a micronutrient element, $\mathrm{Zn}$ is known to interact with some other elements. Some well known interactions are Zn-N [13] [14], Zn-Fe [15], Zn-Mn [16], Zn-Cu, Zn-B [7] and mostly Zn-P which causes "P” induced Zn deficiency [17]. As arsenic (As) and phosphorus (P) are in the same group of periodic table (Group VA) and $\mathrm{Zn}$ and $\mathrm{P}$ bear an antagonistic relationship, it is assumed that $\mathrm{Zn}$ is to show antagonism with As i.e., $\mathrm{Zn}$ is expected to depress arsenic (As) concentration in soils as well as in plants. To substantiate the hypothesis, a plant culture experiment was made where kalmishak (Ipomoea aquatica) was used as the test plants as it is an available fast growing and widely consumed leafy vegetable.

\section{Materials and Methods}

Composite soil samples, collected from the surface $(0-15 \mathrm{~cm})$ of the field of Bangladesh Jute Research Institute (BJRI) of Manikgonj district $\left(23^{\circ} 52^{\prime} 60^{\prime \prime} \mathrm{N}\right.$ and $90^{\circ} 02^{\prime} 12^{\prime \prime} \mathrm{E}$ ), were air-dried, ground and divided into two parts. The first part was passed through a $0.5 \mathrm{~mm}$ sieve and used for analyzing some physical and chemical parameters of the soil. The soil had a $\mathrm{pH}$ of 6.52, silt loam texture, $0.87 \%$ organic carbon, $0.09 \%$ total nitrogen, $0.10 \mathrm{meq} \%$ available potassium, 3.03 $\mathrm{mg}$ available phosphorus and $11.17 \mathrm{mg}$ available sulfur/ $\mathrm{kg}$ soil. Diethylene-triamine-penta-Acetic acid (DTPA) extractable Zn content of the soil was $1.89 \mathrm{mg} / \mathrm{kg}$ and water extractable As content was below the detection limit (0.02 $\mathrm{mg} / \mathrm{L}$ ) of the atomic absorption spectrophotometer (AAS).

Another part of the soil was passed through a $5 \mathrm{~mm}$ sieve and put into 48 earthen pots each having $2 \mathrm{~kg}$ soils for the pot experimentation. To ensure the optimum growth of Kalmi, the test plant species, Nitrogen (N), Phosphorous (P) and Potassium (K) fertilizers were added at a rate of $260 \mathrm{~kg}$ Urea/ha, i.e. 0.259 $\mathrm{g} / 2 \mathrm{~kg}$ soil; $188 \mathrm{~kg} \mathrm{TSP} / \mathrm{ha}$, i.e. $0.188 \mathrm{~g} / 2 \mathrm{~kg}$ soil and $98.5 \mathrm{~kg} \mathrm{MP} / \mathrm{ha}$, i.e. $0.099 \mathrm{~g} / 2$ $\mathrm{kg}$ soil respectively [18].

The experiment was conducted by following a factorial experiment. Four dif- 
ferent doses of $\mathrm{Zn}(0,1,2$ and $3 \mathrm{mg} / \mathrm{L})$ and of As $(0,0.5,1$ and $2 \mathrm{mg} / \mathrm{L})$ were selected as treatments. The different rates of $\mathrm{Zn}$ were supplied as $300 \mathrm{ml} \mathrm{ZnCl} 2$ solution during pot preparation and the doses of As was applied with daily irrigation water. Arsenic solution was prepared by dissolving $80 \% \mathrm{Na}$-meta arsenite and $20 \% \mathrm{Na}$-arsenate and application of As doses were started after 10 days of germination of Kalmi. The control treatments did not receive either $\mathrm{Zn}$ or As. The plants of these pots were irrigated with As free tap water.

Kalmi plants were harvested by uprooting them after 45 days of their growth. Then, after washing and weighing for fresh weight, the samples were cut, oven dried and sieved with $0.2 \mathrm{~mm}$ sieve and digested with concentrated nitric acid for further chemical analysis. On the other hand, soil samples, collected from pots after harvesting of plants, were air dried, ground and sieved through a 0.5 $\mathrm{mm}$ sieve and extracted with DTPA and distilled water for the analysis of $\mathrm{Zn}$ and As respectively.

All the data in the present experiment were statistically analyzed by using Microsoft Excel and MINITAB (version 17) packages. The results of experiment were statistically evaluated in the form of one-way analysis of variance (ANOVA).

\section{Results and Discussion}

The fresh and dry matter yields of Kalmi as affected by the various combinations of As and $\mathrm{Zn}$ treatments are shown in Table 1 and Table 2. The values presented in the tables are averages of three individual replications. There were 5 plants in each pot and the results presented here are in g/100 plant basis.

Table 1 shows that the highest amount of fresh matter was obtained for the treatment combination of $\mathrm{As}_{0.5} \mathrm{Zn}_{0}$ and the minimum amount was produced for the treatment $\mathrm{As}_{0.5} \mathrm{Zn}_{3}$.

On the other hand, as for the dry matter production, $\mathrm{As}_{0.5} \mathrm{Zn}_{3}$ treatment produced the maximum while the minimum amount was obtained for the $\mathrm{As}_{2} \mathrm{Zn}_{1}$ treatment (Table 2). The table also shows that at zero $\mathrm{Zn}$ application and zero As application the fresh matter yield was low. With the increase of As dose to 0.5 $\mathrm{mg} / \mathrm{L}$, yield was increased and attained the highest value. It could be due to the

Table 1. Fresh matter (g/100 plants) production of Kalmi (Ipomoea aquatica) plants at different combinations of As and $\mathrm{Zn}$.

\begin{tabular}{ccccc}
\hline As $\downarrow$ Zn & $0 \mathrm{mg} / \mathrm{L}$ & $1 \mathrm{mg} / \mathrm{L}$ & $2 \mathrm{mg} / \mathrm{L}$ & $3 \mathrm{mg} / \mathrm{L}$ \\
\hline $0 \mathrm{mg} / \mathrm{L}$ & 89.5 & 85.3 & 139.6 & 123.5 \\
$0.5 \mathrm{mg} / \mathrm{L}$ & 148 & 112.2 & 106.4 & 76.3 \\
$1 \mathrm{mg} / \mathrm{L}$ & 125.1 & 101.8 & 107.9 & 144.5 \\
$2 \mathrm{mg} / \mathrm{L}$ & 103.3 & 119.4 & 85.3 & 102.7 \\
P value $\rightarrow$ & $\mathbf{0 . 1 3 6}$ & $\mathbf{0 . 5 3 4}$ & $\mathbf{0 . 0 6 5}$ & $\mathbf{0 . 0 1 0}$ \\
Comment & not significant & not significant & not significant & Significant \\
\hline
\end{tabular}


Table 2. Dry weight (g/100 plants) production of Kalmi (Ipomoea aquatica) plants at different combinations of As and $\mathrm{Zn}$.

\begin{tabular}{ccccc}
\hline As $\downarrow$ \\
$0.5 \mathrm{mg} / \mathrm{L}$ & $0 \mathrm{mg} / \mathrm{L}$ & $1 \mathrm{mg} / \mathrm{L}$ & $2 \mathrm{mg} / \mathrm{L}$ & $3 \mathrm{mg} / \mathrm{L}$ \\
$0.5 \mathrm{mg} / \mathrm{L}$ & 12.3 & 7.2 & 11.1 & 10.7 \\
$1 \mathrm{mg} / \mathrm{L}$ & 10.2 & 9.5 & 8.1 & 12.7 \\
$2 \mathrm{mg} / \mathrm{L}$ & 9.1 & 9.5 & 9.3 & 8.3 \\
P value $\rightarrow$ & $\mathbf{0 . 0 3 4}$ & $\mathbf{0 . 5 1 5}$ & $\mathbf{0 . 0 7 2}$ & $\mathbf{0 . 0 3 0}$ \\
Comment & significant & not significant & not significant & Significant \\
\hline
\end{tabular}

fact that at low concentration of As, the P availability or Fe availability was favored which caused this yield increase. Similar observations were found at low concentration of an antagonistic or otherwise not essential element favor growth with $\mathrm{Na}$ for a different crop [19]. It needs to be further mentioned that the fresh matter yield was better than control for all the other treatments.

The analysis of variance (ANOVA) test indicated that the effect of elevated dose of $\mathrm{Zn}(3 \mathrm{mg} / \mathrm{L})$, on both fresh and dry matter production of Kalmi, over different rates of As application was significant $(\mathrm{P}$ value $=0.010$ for fresh weight and $\mathrm{P}$ value $=0.030$ for dry weight production), whereas the effect of other doses of $\mathrm{Zn}(1$ and $2 \mathrm{mg} / \mathrm{L}$ ) on different levels of As was found to be not significant. On the other hand, when $\mathrm{Zn}$ was absent, the dry matter production showed a significant increase with increasing As in the soil indicating the fact that the soil lacked sufficient $\mathrm{Zn}$ supply $(\mathrm{P}$ value $=0.034)$.

The results (Table 1 and Table 2) clearly indicate that the higher doses of As caused reduction of yield of Kalmi plants, especially when the dry matter production was reduced. It may be due to the harmful impact of As on plant metabolism as As was also reported as a well-known metabolic inhibitor [20]. Supporting this hypothesis, it was also reported that the higher concentrations of As interfere with metabolic processes and inhibit plant growth, sometimes leading to death [21]. Growth reduction of several plants due to higher doses of arsenic was also reported by [22]. Lower biomass production of plants resulting lower synthesis and lower pigment concentration due to increasing levels of As in plant-soil environment was also reported by [23].

Water extractable As in soils and plant As concentration for different combinations As-Zn treatments are shown (Figures 1-4).

It is to be noted that the control treatment where no $\mathrm{Zn}$ was added, showed the maximum concentration of As both for soils and plants, but with the increase in $\mathrm{Zn}$ level, As was found to be decreased. However, a slight increase in the concentration of As, found in native soil in an absolute control treatment $\left(A s_{0} Z_{0}\right)$, was found which could be due to the solubilization of some of the total As by the root exudates (usually the organic acids), or it could have been added as an impurity from the P-fertilizer used. 


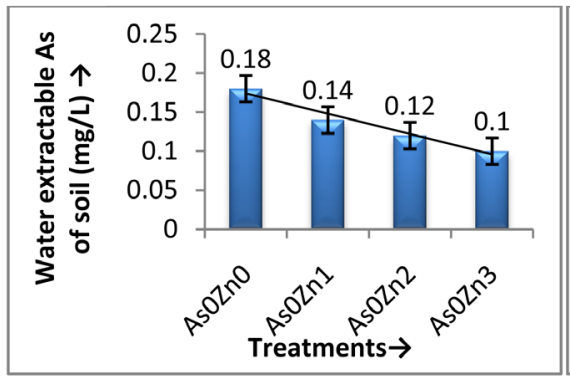

(a)

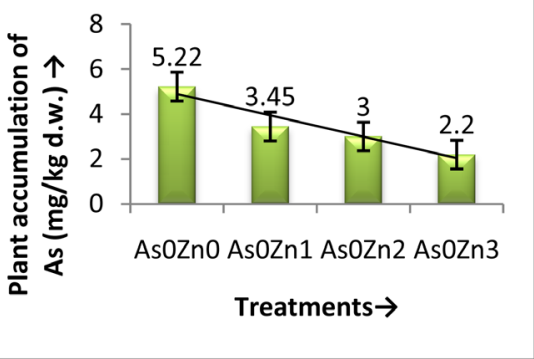

(b)

Figure 1. (a) No As in soils with (b): As in plants at no As in different levels of Zn soil with different levels of $\mathrm{Zn}$.

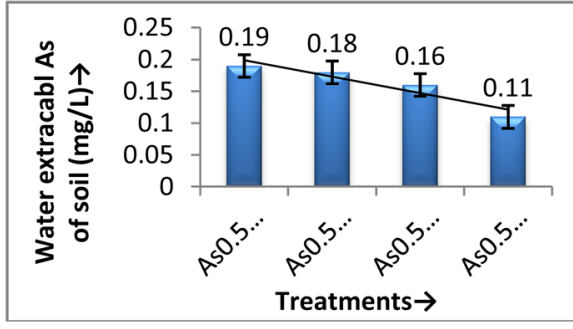

(a)

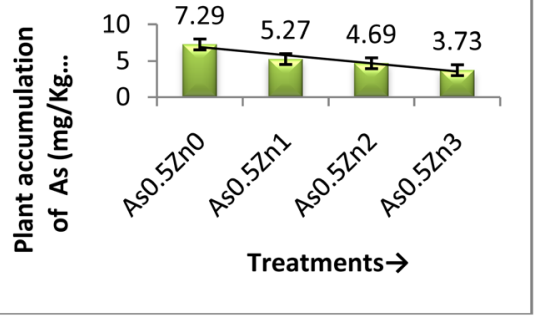

(b)

Figure 2. (a) $0.5 \mathrm{mg} / \mathrm{L}$ of As in soils; (b) As in plants at $0.5 \mathrm{mg} / \mathrm{L}$ of As in soil with different levels of $\mathrm{Zn}$. with different levels of $\mathrm{Zn}$.

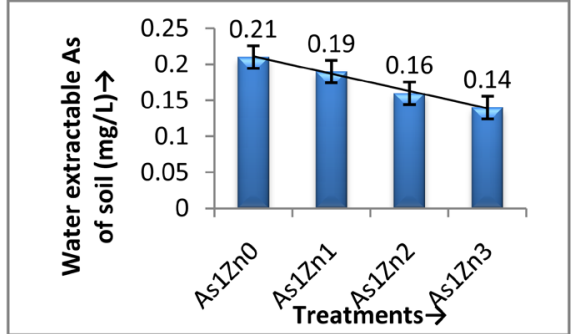

(a)

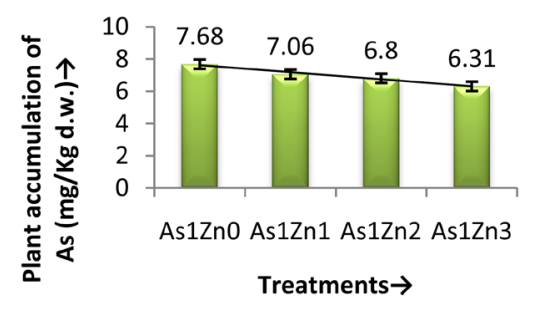

(b)

Figure 3. (a) $1 \mathrm{mg} / \mathrm{L}$ of As in soils; (b) As in plants $1 \mathrm{mg} / \mathrm{L}$ of As in soil with different levels of $\mathrm{Zn}$. with different levels of $\mathrm{Zn}$.

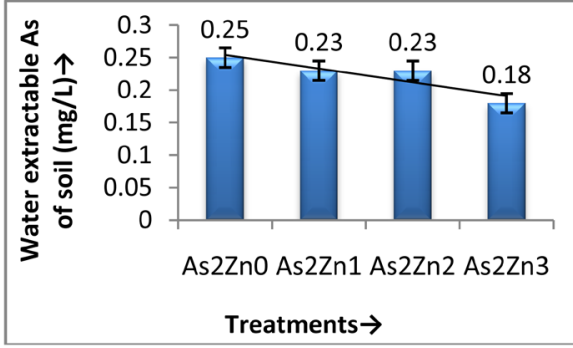

(a)

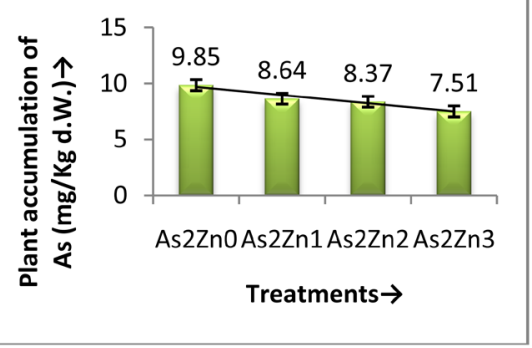

(b)

Figure 4. (a) $2 \mathrm{mg} / \mathrm{L}$ of As in soils; (b) As in plants $2 \mathrm{mg} / \mathrm{L}$ of As in soil with different levels of $\mathrm{Zn}$. with different levels of $\mathrm{Zn}$.

With regard to increasing doses of $\mathrm{Zn}$ fertilization, it was recorded that the As availability was countered indicating an interacting effect between $\mathrm{Zn}$ and As. 
Higher doses of Zn was found to decrease the mobility of As (Figure 1(a), Figure 2(a), Figure 3(a) and Figure 4(a)) in soils as well as the plant Zn concentration (Figure 1(b), Figure 2(b), Figure 3(b) and Figure 4(b)) under the present experimental condition.

One of the causes of such decrease might be the precipitation or fixation of As as $\mathrm{Zn}$-arsenate, which makes it less mobile and unavailable to plants [24].

Arsenate $+\mathrm{ZnCl}_{2} \rightarrow \mathrm{Zn}$ - arsenates (Insoluble and unavailable to the plant)

This tends to indicate that $\mathrm{Zn}$ could alleviate As accumulation in plants. As per the free-ion activity model (FIAM) [25], the uptake of As by kalmi plants was reduced as the free-ion activity or availability of that element was reduced from the surrounding soil solution which is similar to the findings of [26].

This observation also corroborates to the findings that of a similar trend for As-Zn interaction in a submerged soil [27]. Correspondingly, it was reported that the toxicity of arsenic may be reduced by applying sulfates of zinc, iron and aluminum to the soil [28]. An increase in arsenic concentration was correlated with decreasing application of graded levels of $\mathrm{Zn}$ as $\mathrm{Zn}$-sulfate was also reported [29].

All the values of water extractable As in soils and plant uptake of As were found to be highly significant ( $\mathrm{P}$ value $<0.001$ ).

It is evident from the result of the experiment that, higher doses of $\mathrm{Zn}$ fertilizers were found to suppress As availability in soils as well as the plant As contents. In this experiment, it was found that among all the doses, the maximum dose of $\mathrm{Zn}(3 \mathrm{mg} / \mathrm{L})$ had the maximum antagonistic effect on As as it reduced the soil extractable As concentration from 0.25 to $0.18 \mathrm{mg} / \mathrm{kg}$ and the plant As concentrations from 9.85 to $7.51 \mathrm{mg} / \mathrm{kg}$ dry weight for the maximum $\mathrm{Zn}$ dose (3 $\mathrm{mg} / \mathrm{L})$.

On that note, it can be suggested that $\mathrm{Zn}$ fertilizers, especially $\mathrm{ZnCl}_{2}$, can be used to reduce As toxicity from soils as well as to reduce plant As contents, but of course within the critical limit value of $\mathrm{Zn}$ for plants.

\section{References}

[1] Rahman, M.M., Sengupta, M.K., Chowdhury, U.K., Lodh, D., Das, B., Ahmed, S., Hossain, M.A., Mukherjee, S.C. and Pati, S. (2006) Arsenic Contamination Incidents around World. In: Naidu, R., Smith, E., Owens, G., Bhattacharya, P. and Nadebaum, P., Eds., Managing Arsenic in the Environment, from Soil to Human Health, Commonwealth Scientific and Industrial Research Organisation (CSIRO) Publishing, Melbourne, 3-36.

[2] Imamul Huq, S.M. (2008) Fate of Arsenic in Irrigation Water and Its Potential Impact on Food Chain. In: Ahuja, S., Ed., Arsenic Contamination of Groundwater. Mechanism, Analysis and Remediation, John Wiley \& Sons, Inc., New York, 25-49.

[3] Imamul Huq, S.M., Smith, R., Smith, L., Smith, J., Roy, S., Barnes, M. and Naidu, R. (2001) Arsenic Transfer in Water-Soil-Crop Environment in Bangladesh. Arsenic in the Asia-Pacific Region Workshop, Adelaide, 50-52.

[4] Imamul Huq, S.M. and Naidu, R. (2003) Arsenic in Groundwater of Bangladesh: Contamination of the Food Chain. In: Ahmed, M.F., Ed., Arsenic Contamination: Bangladesh Perspective, Center for Water Supply and Waste Management, Bang- 
ladesh University of Engineering and Technology (BUET), Dhaka, 15-35.

[5] Sommer, A.L. and Lipman, C.B. (1926) Evidence on the Indispensable Nature of Zinc and Boron for Higher Green Plant. Plant Physiology, 1, 231-249.

https://doi.org/10.1104/pp.1.3.231

[6] Pais, I. and Jones Jr., J.B. (1997) The Handbook of Trace Elements. St. Luice Press, Boca Raton.

[7] Mousavi, S.R., Galavi, M. and Rezael, M. (2012) The Interaction of Zinc with Other in Plants: A Review. International Journal of Agriculture and Crop Sciences, 4, 1881-1884.

[8] Ronen, E. (2007) Micro-Elements in Agriculture. Practical Hydroponics and Greenhouses. International Journal of Agriculture and Crop Sciences, 3, 39-48.

[9] Marschner, H. (1995) Mineral Nutrition of High Plant. Academic Press, USA, 330355.

[10] Outten, C.E. and O'Halloran, T.V. (2001) Femtomolar Sensitivity of Metalloregulatory Protein Controlling Zn Homeostasis. Science, 292, 2488-2492. https://doi.org/10.1126/science.1060331

[11] Pandey, N., Pathak, G.C. and Sharma, C.P. (2006) Zinc Is Critically Required for Pollen Function and Fertilization in Lentil. Journal of Trace Elements in Medicine and Biology, 20, 89-96. https://doi.org/10.1016/j.jtemb.2005.09.006

[12] http://www.ehow.com./facts 7691378 zinc-soils-plants.html\#ixzz2nzlOUFXE

[13] Dev, M. and Sukla, U.C. (1980) N-Zn Content in Maize Affected by Their Different Sources. Journal of Indian Society of Soil Science, 28, 336-341.

[14] Kumar, V., Ahlawat, S. and Antil, R.S. (1985) Interactions of Nitrogen and Zinc in Pearl Millet. Effect of Nitrogen and Zinc Levels in Dry Matter Yield and Concentration and Uptake of Nitrogen and Zinc in Pearl Millet. Soil Science, 139, 351-356. https://doi.org/10.1097/00010694-198504000-00009

[15] Mukhi, A.K. and Shukla, U.C. (1987) Iron and Zinc Relationship in Rice Grown in Submerged Soils. Journal of Indian Society of Soil Science, 35, 685-689.

[16] Lingle, J.C. and Holmberg, D. (1957) The Response of Sweet Corn to Foliar and Soil Zinc Application on Zinc Deficient Soil. Soil Science Society of America Journal, 70, 308-315.

[17] Burleson, C.A., Dacus, A.D. and Gernard, C.J. (1961) The Effect of Phosphorus Fertilization in the Zinc Nutrition of Several Irrigated Crops. Soil Science Society of America Journal, 25, 365-368. https://doi.org/10.2136/sssaj1961.03615995002500050018x

[18] Bangladesh Agricultural Research Council (BARC) (2005) Fertilizer Recommendation Bangladesh Guide. BARC Soils Publication No. 45, BARC, Dhaka, 1-254.

[19] Imamul Huq, S.M. and Larher, F. (1983) Osmoregulation in Higher Plants: Effects of $\mathrm{NaCl}$ Salinity on Non-Nodulated Phaseolus aureus L. I. Growth and mineral contents. New Phytologist, 93, 203-208. https://doi.org/10.1111/j.1469-8137.1983.tb03424.x

[20] Kabata-Pandias, A. and Pandias, H. (2001) Trace Elements in Soils and Plants. CRS Press, Boca Raton, Florida.

[21] Martin, A.R., Masscheleyn, P.H. and Patrick, W.H.J. (1992) The Influence of Chemical Form and Concentration of Arsenic on Rice Growth and Tissue Arsenic Concentration. Plant and Soil Journal, 139, 175-183. https://doi.org/10.1007/BF00009308

[22] Stoeva, N., Berova, M. and Zlatev, Z. (2003) Physiological Response of Maize to Ar- 
senic Contamination. Biologia Plantarum, 47, 449-452. https://doi.org/10.1023/B:BIOP.0000023893.12939.48

[23] Mishra, S., Starkb, H.J. and Kupper, H. (2014) A Different Sequence of Events than Previously Reported Leads to Arsenic-Induced Damage in Ceratophyllum demersum L. Metallomics, 6, 444-454. https://doi.org/10.1039/c3mt00317e

[24] Craw, D. and Chappell, R. (2000) Metal Redistribution in Historic Mine Wastes. New Zealand Journal of Geology and Geophysics, 43, 187-189. https://doi.org/10.1080/00288306.2000.9514880

[25] Degryse, F., Smolders, E. and Parker, D.R. (2006) Metal Complexes Increase Uptake of $\mathrm{Zn}$ and $\mathrm{Cu}$ by Plants: Implications for Uptake and Deficiency Studies in Chelator-Buffered Solutions. Plant and Soil Journal, 289, 171-185.

https://doi.org/10.1007/s11104-006-9121-4

[26] Suzuki, K.T. (2002) A Speciation Study Focused on the Identification of Proximate Toxic Arsenic Metabolites. Proceedings of the UNU-NIES International Workshop on Arsenic Contamination in Groundwater-Technical and Policy Dimensions, Tokyo, 18 February 2002, 25-26.

[27] Garai, T.K., Das, D.K. and Sarkar, S. (2000) Effect of Iron and Zinc Application on the Availability of Native and Applied Arsenic Simulating Low Land Rice Condition. Paper Presented at the International Conference on Managing Natural Resources for Sustainable Agricultural Production in the 21 st Century, New Delhi, 14-18 February 2000, 14-18.

[28] Brady, N.C. and Weil, R.R. (2004) The Nature and Properties of Soils. Prentice Hall, Upper Saddle River, New Jersey, 638-666.

[29] Das, D.K., Garai, T.K., Sarkar, S. and Pintu, S. (2005) Interaction of Arsenic with Zinc and Organics in a Rice (Oryza sativa L.) Cultivated Field in India. The Scientific World Journal, 5, 646-651. https://doi.org/10.1100/tsw.2005.60

\section{Submit or recommend next manuscript to SCIRP and we will provide best service for you:}

Accepting pre-submission inquiries through Email, Facebook, LinkedIn, Twitter, etc. A wide selection of journals (inclusive of 9 subjects, more than 200 journals)

Providing 24-hour high-quality service

User-friendly online submission system

Fair and swift peer-review system

Efficient typesetting and proofreading procedure

Display of the result of downloads and visits, as well as the number of cited articles

Maximum dissemination of your research work

Submit your manuscript at: http://papersubmission.scirp.org/

Or contact jacen@scirp.org 